\title{
Tænketanke i dansk politik
}

Jesper Dahl Kelstrup, 2018

Tænketanke - nye aktører i dansk politik

DJØF Forlag, København

128 sider, $240 \mathrm{kr}$.

Anmeldt af Morten Jarlbæk Pedersen, cand. scient. pol., ph.d.

"Etableringen af den borgerlig-liberale tænketank Cepos i 2004 har været medvirkende til, at begrebet tænketank gradvist er blevet et flittigt benyttet ord i dansk politik... Alligevel eksisterer der ikke nogen samlet fremstilling af tænketanke i Danmark." (Kelstrup 2018, 9)

Cirka således indleder Jesper Dahl Kelstrup sin nye bog om tænketanke. Ambitionsniveauet er højt: Målet er at give en samlet fremstilling af tænketanke i Danmark. Måske er ambitionsniveauet også en smule for højt, når der er tale om en bog på små 130 sider inklusiv en rig og fyldig litteraturliste. I hvert fald formår bogen ikke helt at overbevise denne læser om, at der er tale om dækkende fremstilling.

Ikke desto mindre giver bogen anledning til en række refleksioner af ganske forskellig karakter - og det er jo i sig selv en meget positiv og opløftende bivirkning. Den første refleksion går på selve tænketankenes natur. For bogen beskæftiger sig kun overfladisk med det ellers temmelig grundlæggende spørgsmål: Hvad er en tænketank egentlig for en størrelse? I forlængelse heraf bliver det naturligt at fundere en smule over den rolle og funktion, som tænketanke udfylder i dagens Danmark: Hvorfor har vi overhovedet tænketanke? Bogen forholder sig til begge spørgsmål, men altså ikke i tilstrækkelig klare termer til, at denne anmelder ikke nedenfor vil tillade sig et par supplerende om end overfladiske refleksioner.

Inden vi når dertil, bør det dog slås fast, at yderligere én refleksion trænger sig på. Nemlig spørgsmålet om, hvad det overhovedet er for en bog, vi har med at gøre? For at kunne vurdere, om bogen lever op til sine ambitioner, skal man nemlig have en nogenlunde entydig forestilling om, hvad det er for en bog. Og bogens mest fremtrædende akilleshæl er, at dette er uklart.

\section{Hvem er bogen skrevet til?}

"Tænketanke" består af tre dele. Den første del - de første næsten 60 sider - fokuserer på de teoretiske perspektiver på tænketanke, og først derefter kommer vi til bogens egentlige 
anliggende, nemlig den samlede fremstilling af tænketanke i Danmark, der er emnet for de to andre dele af bogen.

Bogens første del er således skrevet for at skabe et teoretisk grundlag for de diskussioner og analyser, der præsenteres efterfølgende, mens resten indeholder disse konkrete analyser og diskussioner. Udfordringen er, at de to dele synes skrevet til forskellige målgrupper, hvilket desværre giver bogen et noget usammenhængende præg. Det er således uklart for denne læser, om bogen er skrevet for de allerede indviede - forskere og andre kendere af den eksisterende forskningslitteratur om tænketanke - eller om bogen er skrevet med formidling til en bredere modtagerkreds for øje. Og problemet med ikke at vælge den ene eller den anden målgruppe er, at man i så fald vælger ingen. Og bogens lidt tandløse konklusion om, at "[d]et danske landskab af tænketanke og dets udvikling (...) fortjener på den baggrund fortsat opmærksomhed og diskussion" (Kelstrup 2018, 113) understreger blot, at vi har at gøre med et værk, der desværre ikke rigtig tør tage stilling til sig selv.

I bogens første og teoretiske del kommer vi således vidt omkring i det teoretiske landskab. Der er tale om et langt og uafbrudt skoleridt gennem tænketankslitteraturen. For den, der studerer og forsker i tænketanke, er bogens første del sandsynligvis en god - og samlet - fremstilling. For den, der ikke på forhånd har et temmelig indgående kendskab til det teoretiske landskab på området, er der snarere tale om "information overload", og relationen til den danske virkelighed er ikke i centrum, som man ellers som lægmand ville forvente og ønske sig. Enkelte steder får man endda oplevelsen af, der nævnes mange teoretikere, men få teorier; det gælder f.eks. i kapitlet om tænketankes politiske indflydelse. Det behøver bestemt ikke være tilfældet - men for den uindviede kan det være oplevelsen. Og det er sådan set ærgerligt, for der er flere af de teoretiske diskussioner, der i den grad er relevante også i en dansk sammenhæng - som f.eks. diskussionerne om tænketankes indflydelse eller forhold til de politiske partier.

I bogens anden og tredje del præsenteres et forsøg på en kategorisering af de danske tænketanke og efterfølgende en række analyser af f.eks. deres gennemslagskraft i medierne. Modsat bogens første del er denne del både lettilgængelig og letfordøjelig. Målgruppen synes dermed en helt anden end for bogens første del.

Måske er denne problemstilling indarbejdet i enhver forskningsformidling, og den beskrevne oplevelse diskvalificerer på ingen måde det arbejde, som Jesper Dahl Kelstrup præsenterer i bogen. Det betyder dog, at bogen måske leverer en samlet, men desværre ikke helt en samlende fremstilling af tænketankene i Danmark. Og det er i grunden ærgerligt, thi både bogens emnefelt og bogens analyser er ganske relevante for at forstå det politiske landskab i Danmark i dag. 


\section{Hvad er en tænketank egentlig?}

Men hvad er det så, Jesper Dahl Kelstrup kigger nærmere på i bogen? Hvad er en tænketank egentlig for en størrelse? Hvorved adskiller en tænketank sig fra andre politisk-analytiske organisationer?

Dette spørgsmål er så banalt og så simpelt, at det tilsyneladende er umuligt at svare entydigt på. I bogen bruges således heller ikke meget energi på denne diskussion, idet man allerede på første side i introduktionen kan læse, at en tænketank er en "organisation, der hævder uafhængighed og søger politisk indflydelse ved at synliggøre ekspertviden" (Kelstrup 2018,9). Denne definition er muligvis tilstrækkelig - men man kunne have ønsket sig en lidt dybere diskussion af den og den kontekst, som den er skabt for at afspejle. For hvad er egentlig tænketankenes forhold og grænseflade til andre og lignende politiske aktører?

Gennem de seneste ti-tyve år har man eksempelvis i erhvervsorganisationerne og andre interesseorganisationer oprustet endog ganske kraftig på analysekræfterne. Og disse organisationer hævder jo også politisk uafhængighed (fra partierne i hvert fald) og beskæftiger sig som regel med emner inden for afgrænsede nicher. Lidt groft kan man måske endda sige, at den eneste forskel mellem den moderne erhvervsorganisation og en tænketank synes at være spørgsmålet om medlemmer.

Det er da også denne forfatters indtryk, at man i erhvervsorganisationerne efterhånden opfatter (nogle af) tænketankene som direkte konkurrenter om virksomhedernes økonomiske gunst; virksomheden kan jo ligeså vel kan sende deres penge i retningen af CEPOS som i retning af Dansk Erhverv, hvis virksomheden ønsker at præge den offentlige debat, men ikke ønsker selv at engagere sig eller blive sovset ind i det etablerede arbejdsgiveri og overenskomstsystem.

Jesper Dahl Kelstrup prioriterer ikke disse refleksioner i sin bog - og det præger også den typologi for tænketanke, som måske er bogens originale, teoretiske bidrag. I bogen skelnes mellem fire typer af tænketanke: De offentlige og de partinære, der begge er offentligt finansierede - og advocacy og policy-tænketanke, der begge er privatfinansierede.

Skellet mellem de to sidste synes dog mere teoretisk end empirisk gangbart, idet skellet mellem dem afgøres af tænketankens valgte strategi og ikke af tænketankens natur eller organisation. Dermed synes Jesper Dahl Kelstrup implicit at acceptere flere af policy-tænketankenes ønske om at blive betragtet som apolitiske aktører eller aktører, der alene afgiver politiske råd på baggrund af nøgtern hvis ikke objektivt grundlag. Man behøver ikke have deltaget ret længe i den offentlige debat for at kunne konstatere, at det $\mathrm{i}$ al fald ikke altid er tilfældet. 


\section{Hvilken funktion udfylder tænketanke (i Danmark)?}

Og disse tanker om tænketankes plads i den offentlige debat bringer os naturligt til de næste par overvejelser. I den første del af bogen berører Jesper Dahl Kelstrup en række teoretiske perspektiver på de funktioner og roller, som tænketanke kan udfylde - men bogens konklusion om, hvordan det ser ud i Danmark, er ikke helt så klar.

Eksempelvis fremprovokerer tænketankenes snitflader til de politiske partier en række refleksioner. Jesper Dahl Kelstrup viser tydeligt og overbevisende, at vi i Danmark ikke har partinære tænketanke, som man f.eks. ser det i Tyskland. Men betyder medialiseringen af politik - at den politiske logik i stadig tiltagende grad skal tilpasses en medielogik - ikke også, at partierne ikke længere kan eller vil være motorer for den mere dristige politikudvikling og samfundspåvirkning i bredere forstand? Og udfylder tænketankene derved ikke et tomrum i den politiske ide- og visionsudvikling? I bogen berøres denne mulighed ved at henvise til, at en række politiske aktører - herunder partipolitiske aktører - selv peger på det. Men måske er der tale om en temmelig grundlæggende og mere kompleks problemstilling, der nok kunne bruge en dybere udredning.

\section{Konklusion}

Alt i alt har Jesper Dahl Kelstrup begået en interessant bog, der qua sit emnevalg og fokus falder på et meget tørt sted. Desværre falder bogen mellem to stole - er der tale om en oversigtsbog til kollegerne eller en analyse til et bredere publikum? - hvorved mange af bogens ellers interessante perspektiver desværre går tabt. Dette betyder i anden række, at det bliver svært at hive en bredere og mere samfundsrelevant konklusion ud af bogen. Hvad mener forfatteren egentlig? Er tænketanke en fordel eller ulempe? Hvad er fremtidsperspektiverne? Bør vi gøre dette eller hint i håndteringen af dem? Hvad er de demokratiske implikationer? Disse spørgsmål besvares ikke tilstrækkelig tydeligt, selvom det er lige præcis dem, vi gerne vil have forfatterens kvalificerede svar på. Til gengæld giver bogen det grundlæggende overblik, der skal til, for at vi kan åbne for diskussionen. Og det er i sig selv både agtværdigt og vigtigt.

\section{Litteratur}

Kelstrup, J. D. (2018). Tanketanke - nye aktører i dansk politik. København: DJØF Forlag 